\title{
A COMPARATIVE STUDY OF INVASIVE Helianthus annuus POPULATIONS IN THEIR NATURAL HABITATS OF ARGENTINA AND SPAIN
}

\author{
Poverene, M. $^{* 1,2}$, Cantamutto, M. $^{1}$
}

${ }^{1}$ Department of Agronomy, Universidad Nacional del Sur, 8000 Bahia Blanca, Argentina

${ }^{2}$ Centro de Recursos Naturales Renovables de la Zona Semiárida (CERZOS-CONICET)

Received: March 18, 2010 Accepted: May 28, 2010

\section{SUMMARY}

Wild Helianthus annuus is native to North America but it naturalized in other parts of the world as well. Although the origin of exotic populations is uncertain, they have probably evolved very differently in different countries. To unravel the origin of invasive populations from Argentina and Spain, morphological and agro-ecological data of nine populations from central Argentina, six from Andalusia and one from Gerona were collected in their natural habitats during three exploration trips in 2007 and 2008. In Argentina wild H. annuus was found mainly in disturbed areas between roads and fences. In a few cases the populations were located on the margins of cultivated fields. The Argentinean populations are spread across more than $50,000 \mathrm{~m}^{2}$ at a density of about 25 plants $\mathrm{m}^{-2}$. In Spain, the populations were found mainly in croplands. The largest population covered about $1,500 \mathrm{~m}^{2}$ and comprised no more than 200 plants. The Argentinean populations had taller plants with a higher number of heads of small size, while the Spanish populations were characterized by bigger heads with wider ligules and bracts. Plants were shorter and leaf size was larger in Gerona than in Andalusia. Multivariate analysis differentiated populations from Argentina and Spain by many traits. Wild-crop gene flow is likely the source of genetic variation among them. In Argentina, the populations keep the appearance of early wild introductions, while the Spanish populations are weedier and probably originated from pollen contamination of commercial seed with wild plants or crop-wild hybrids.

Key words: weedy sunflower, gene flow, diversity, morphology, naturalized

* Corresponding author: Phone: 54291 4595102; Fax: 54291 4595127;

e-mail: poverene@criba.edu.a 


\section{INTRODUCTION}

Wild Helianthus annuus is native to North America but is also found in other parts of the world. In Europe it is present in several countries, such as France (Faure et al., 2002), the Czech Republic (Holec et al., 2005), Spain (Muller et al., 2006), and Italy (Vischi et al., 2006), and has been reported ephemerally in other countries as well (Holec et al., 2005). This species and other wild Helianthus species are also present in Australia (Dry and Burdon, 1986; Seiler et al., 2008), Argentina (Poverene et al., 2002), and South Africa (Vischi et al., 2004), and are now widespread over all the continents. The origin of exotic populations is uncertain. The authors above cite intentional and inadvertent introductions, mostly as contaminants of forage seed or litter for animals or escapes from gardens.

Wild H. annuus is established in central Argentina (Poverene et al., 2008), Australia (Seiler et al., 2008), France and Spain (Muller et al., 2009), where it is found in crop fields and in uncultivated places. Although it is a recognized germplasm source for several valuable traits that can be transferred to cultivated sunflower (Jan and Seiler, 2007), wild sunflower is also an invasive species for summer crops and pastures (Geier et al., 1996; Marshall et al., 2001; Deines et al., 2004). In particular, it can become troublesome for sunflower crops, given their genetic similarity that allows gene flow in both directions, wild-to-crop and crop-to wild (Reagon and Snow, 2006; Ureta et al., 2008a). Naturalized strains probably have evolved very differently in different countries and it would be of interest to know if there are any adapted ecotypes that could provide novel traits for sunflower breeding, i.e. resistance to biotic or abiotic constraints. In Argentina wild $H$. annuus grows in a wide range of agro-ecological environments (Cantamutto et al., 2008). Phenotypic characterization under common garden conditions revealed a high variability between Argentinean accessions and enough differentiation from the native populations to qualify them as a novel genetic resource (Presotto et al., 2009a; Cantamutto et al., 2010a). The goal of the present work was to examine and compare invasive populations from Argentina and Spain in an attempt to unravel their origin.

\section{MATERIALS AND METHODS}

Study materials from both countries were collected in their natural habitats during three exploration trips in 2007 and 2008. Wild strains from Argentina included nine representative Helianthus annuus populations from different geographic regions in the central part of the country (Table 1). Of the seven populations from Spain, six were collected in Andalusia and one in Gerona (Table 2).

Agro-ecological and morphological data were scored as follows:

Habitat data: On the basis of latitude and longitude of each population, climatic data from the nearest locality were scored: latitude $\left({ }^{\circ}\right)$, altitude (mosl), day- 
light of the longest day ( $\mathrm{min})$, rainfall $(\mathrm{mm})$, mean temperature of the hottest month and mean temperature of the coldest month $\left(^{\circ}\right)$. The climate data for Spain were taken from Agencia Estatal de Meterología (AEMET) of the Spanish government. The climatic data for Argentinean locations were estimated according to Cantamutto et al. (2008). Data for two of the Argentinean populations, located in the irrigated zones of San Juan and Mendoza provinces, were adjusted by adding $500 \mathrm{~mm}$ to the annual rainfall. Additional data on the location of the population were roadside (yes/no), waterside (yes/no), close distance to crops: sunflower, corn, wheat (yes/no), inside sunflower crop (yes/no), presence of sunflower volunteers (yes/no).

Table 1: Helianthus annuus populations from Argentina evaluated in their natural habitats

\begin{tabular}{lccc}
\hline Population & UNS code & Nearest town and Province & Site description \\
\hline DIA & 1007 & Diamante, Entre Rios & Crags along Parana river \\
JCE & 1107 & La Carlota, Córdoba & Roadsides of Hwy 4 \\
RCU & 1207 & Rio Cuarto, Cordoba & Roadside, dirt road \\
MAG & 1407 & Media Agua, San Juan & Field margins close to a vineyard \\
LMA & 1507 & San Rafael, Mendoza & Field margin and dirt road \\
RAN & 2007 & Rancul, La Pampa & Roadside of Hwy. 188 \\
BAR & 2307 & Colonia Barón, La Pampa & Roadside of Hwy 10 \\
AAL & 2807 & Puan, Buenos Aires & Along a ditch near a malting factory \\
CHU & 2907 & Carhué, Buenos Aires & Along a ditch \\
\hline
\end{tabular}

Table 2: Helianthus annuus populations from Spain evaluated in their natural habitats

\begin{tabular}{|c|c|c|c|}
\hline Population & UNS code & Nearest town and Province & Site description \\
\hline COR & $0108 \mathrm{E}$ & Cordoba, Cordoba, Andalusia & Fallow land close to sunflower crop \\
\hline BUJ & 0308E & Bujalance, Cordoba, Andalusia & $\begin{array}{l}\text { Narrow land between a reed bed } \\
\text { and a sunflower crop }\end{array}$ \\
\hline FNU & $0408 \mathrm{E}$ & $\begin{array}{c}\text { Fernan Nunez, Cordoba, } \\
\text { Andalusia }\end{array}$ & Roadside close to a sunflower crop \\
\hline MON & 0508E & Montilla, Cordoba, Andalusia & Roadside \\
\hline MBA & 0608E & $\begin{array}{l}\text { Posadas (Molino Bajo), } \\
\text { Cordoba, Andalusia }\end{array}$ & Within sunflower crop \\
\hline PAL & 0708E & $\begin{array}{c}\text { Palma del Rio, Cordoba, } \\
\text { Andalusia }\end{array}$ & Roadside \\
\hline GER & 0908E & St. Pere Pescador, Gerona & Borders of wheat crop \\
\hline
\end{tabular}

Plant traits: Branching type (no, basal, apical, full branching); presence of main head (yes/no); plant height $(\mathrm{cm})$; stem diameter at mid-height $(\mathrm{cm})$.

Leaf traits: Leaf length and width $(\mathrm{cm})$; petiole length $(\mathrm{cm})$; leaf base (cuneate, cordate); leaf shape (oblate, triangular, cordate, lance or round-shaped); leaf surface (flat, waxy, curled); leaf margin (smooth, serrate, deeply serrate); anthocyanin in stem and petioles (yes/no).

Inflorescence traits: Head position $\left({ }^{\circ}\right)$; dorsal leaflet (yes/no); number of heads (n); number of ray flowers $(\mathrm{n})$; ray length and width $(\mathrm{cm})$; bract (phyllary) number 
(n); bract pubescence (range from 0, 25, 50, 75 y 100\%); bract length and width $(\mathrm{cm})$; head diameter $(\mathrm{cm})$; disk flower color (yellow, red).

Separate Kruskal-Wallis tests (a non parametric ANOVA test) were performed for all traits showing variation among and/or within populations. The origins were compared considering all the populations nested in the countries as replicates.

Multivariate analysis comprised Discriminant, Principal Component (PCA) and Cluster analyses on individual measures and mean (metrics) or frequency (categorical) values per population. Classification employed the hierarchical agglomerative clustering method with Gower distance as the similarity measure (Gower, 1971).

\section{RESULTS AND DISCUSSION}

\section{Habitat}

The Argentinean $H$. annuus populations were found at a lower latitude than in the centre of origin (Cantamutto et al., 2010a). The Spanish populations were located at a higher latitude than Argentinean ones and as a consequence grew under longer-day, dryer and hotter conditions than the populations in Argentina (Table 3).

Table 3: Environmental and ecological variables of wild sunflower habitats in Argentina and Spain. Difference significance by the Kruskal-Wallis non parametric test

\begin{tabular}{lccc}
\hline $\begin{array}{l}\text { Environmental } \\
\text { variables }\end{array}$ & Argent. & Spain & Sign. \\
\hline Latitude $\left({ }^{\circ}\right)$ & 34.64 & 38.29 & $* * *$ \\
Altitude (m.o.s.l.) & 276.8 & 193.9 & $\mathrm{~ns}$ \\
Daylight (h:min) & 14.20 & 14.40 & $* \star *$ \\
Rainfall (mm) & 702 & 549 & $\star \star$ \\
\hline Mean Temperature $\left({ }^{\circ} \mathrm{C}\right)$ \\
Hottest month & 24.2 & 26.7 & $*$ \\
Coldest month & 8.12 & 8.84 & $*$ \\
\hline
\end{tabular}

\begin{tabular}{lccc}
\hline $\begin{array}{l}\text { Ecological } \\
\text { variables }\end{array}$ & Argent. & Spain & Sign. \\
\hline Roadside & 0.67 & 0.43 & $\mathrm{~ns}$ \\
Waterside & 0.44 & 0.00 & $\mathrm{~ns}$ \\
Sunflower crop & 0.33 & 0.57 & $\mathrm{~ns}$ \\
Maize crop & 0.22 & 0.14 & $\mathrm{~ns}$ \\
Wheat crop & 0.00 & 0.29 & $\mathrm{~ns}$ \\
Volunteers & 0.22 & 0.14 & $\mathrm{~ns}$ \\
Inside crop & 0.00 & 0.86 & $\star \star \star$ \\
\hline
\end{tabular}

${ }^{7}$ mean values; ${ }^{2}$ frequencies

Wild $H$. annuus was introduced to Argentina for agronomic purposes and probably escaped from cultivation and spread (Bauer, 1991) over extended areas in the central part of the country covering a wide range of agro-ecological conditions (Poverene et al., 2002; Cantamutto et al., 2008). At present, the wild sunflower grows mainly in disturbed areas between roads and fences (Poverene et al., 2008). In a few cases the populations have invaded croplands, although they are usually located on the margins of cultivated fields (Table 4). In Spain, by contrast, the wild sunflower is frequently present within the crops, so six out of the seven populations from our study were found in that type of environment. Only one small population was located in a non-tilled area, near an olive plantation. The Argentinean populations cover more than $50,000 \mathrm{~m}^{2}$ and have a density of about 25 plants $\mathrm{m}^{-2}$. In Spain, the largest population covers an area of about $1,500 \mathrm{~m}^{2}$ and comprises no more than 200 plants (Table 4). 
Table 4: Ecological conditions of sampled Helianthus annuus populations

\begin{tabular}{|c|c|c|c|}
\hline Population & Habitat & Demography & Other data \\
\hline \multicolumn{4}{|c|}{ Argentina } \\
\hline DIA & $\begin{array}{l}\text { Crags and riverside, } \\
100 \text { m wide. Clay and } \\
\text { calcareous soils }\end{array}$ & $\begin{array}{l}>1000 \text { plants } \\
\text { in patches } \\
\text { along } 2 \mathrm{~km}\end{array}$ & $\begin{array}{l}\text { Big plants, } \\
\text { long life cycle }\end{array}$ \\
\hline JCE & $\begin{array}{l}\text { Roadside with no volunteers } \\
\text { or intermediate plants }\end{array}$ & $\begin{array}{l}>100,000 \text { plants } \\
\text { along } 10 \mathrm{~km}\end{array}$ & $\begin{array}{l}\text { Dense population, } \\
\text { very tall plants }\end{array}$ \\
\hline $\mathrm{RCU}$ & $\begin{array}{l}\text { Dirt road near the city, } \\
15 \text { m wide both roadsides }\end{array}$ & $\begin{array}{l}\text { ca. } 20,000 \text { plants } \\
\text { along } 2 \mathrm{~km}\end{array}$ & $\begin{array}{l}\text { Dense population, } \\
\text { big plants }\end{array}$ \\
\hline MAG & $\begin{array}{c}\text { Fallow land near a vineyard, } \\
\text { irrigated }\end{array}$ & $\begin{array}{l}>8000 \text { plants } \\
\text { on } 24,000 \mathrm{~m}^{2}\end{array}$ & $\begin{array}{l}\text { Dense population, } \\
\text { shorter plants }\end{array}$ \\
\hline LMA & $\begin{array}{l}\text { Dirt road near town, } \\
\text { along corn crop margins }\end{array}$ & $\begin{array}{l}\text { ca. } 5000 \text { plants } \\
\text { on } 1700 \mathrm{~m}^{2}\end{array}$ & $\begin{array}{l}\text { Possible introgression } \\
\text { of cultivated sunflower }\end{array}$ \\
\hline RAN & $\begin{array}{l}\text { Roadside close to rangeland and } \\
\text { xerophytic shrubs }\end{array}$ & $\begin{array}{l}32 \text { plants } \\
\text { on } 1300 \mathrm{~m}^{2}\end{array}$ & $\begin{array}{l}\text { Loose population, } \\
\text { variable morphology }\end{array}$ \\
\hline BAR & $\begin{array}{l}\text { Roadside close to soybean, } \\
\text { corn and alfalfa crops, volunteers } \\
\text { and } H \text {. petiolaris present }\end{array}$ & $\begin{array}{l}\text { ca. } 12,000 \text { plants } \\
\text { on } 62,000 \mathrm{~m}^{2}\end{array}$ & $\begin{array}{l}\text { Big plants, not dense } \\
\text { but numerous }\end{array}$ \\
\hline $\mathrm{AAL}$ & $\begin{array}{l}\text { Along a ditch of } 1200 \mathrm{~m} \text {, } \\
\text { close to sunflower crop } \\
\text { and volunteers }\end{array}$ & $\begin{array}{l}\text { Two patches of } 6600 \\
\text { and } 1800 \text { plants each }\end{array}$ & $\begin{array}{l}\text { Dense population, } \\
\text { shorter plants }\end{array}$ \\
\hline $\mathrm{CHU}$ & $\begin{array}{c}\text { Dirt road, } H \text {. petiolaris } \\
\text { volunteers or intermediate plants } \\
\text { present }\end{array}$ & $\begin{array}{l}\text { ca. } 2600 \text { plants } \\
\text { on } 8,400 \mathrm{~m}^{2}\end{array}$ & $\begin{array}{l}\text { Possible introgression with } \\
\text { cultivated sunflower }\end{array}$ \\
\hline \multicolumn{4}{|c|}{ Spain } \\
\hline COR & $\begin{array}{l}\text { Fallow land between sunflower } \\
\text { and wheat crops. Some plants } \\
\text { among sunflower crops }\end{array}$ & $\begin{array}{l}80-100 \text { plants on } \\
\text { a patch of } 10 \mathrm{~m} \\
\text { diameter }\end{array}$ & $\begin{array}{l}\text { Red discs and } \\
\text { male-sterility } \\
\text { among plants }\end{array}$ \\
\hline BUJ & $\begin{array}{l}\text { Feral plants on the border } \\
\text { of a sunflower crop }\end{array}$ & $\begin{array}{l}\text { Less than } 100 \text { on } \\
\text { a patch of } 1440 \mathrm{~m}^{2}\end{array}$ & $\begin{array}{l}\text { Many crop traits } \\
\text { among plants }\end{array}$ \\
\hline FNU & $\begin{array}{l}\text { Roadside and border } \\
\text { of sunflower crop }\end{array}$ & $\begin{array}{l}150-200 \text { plants on } \\
\text { a patch of } 1200 \mathrm{~m}^{2}\end{array}$ & $\begin{array}{l}\text { Crop-wild traits } \\
\text { and male sterility }\end{array}$ \\
\hline MON & $\begin{array}{l}\text { Roadside close to } \\
\text { olive plantation }\end{array}$ & $\begin{array}{l}150-200 \text { plants } \\
\text { on } 140 \mathrm{~m}^{2}\end{array}$ & $\begin{array}{l}\text { Wild appearance, } \\
\text { dense pubescence }\end{array}$ \\
\hline MBA & $\begin{array}{l}\text { Wild-type plants in } \\
\text { a sunflower crop }\end{array}$ & $\begin{array}{l}\text { 5-7 plants } \\
\text { per } 100 \mathrm{~m}^{2}\end{array}$ & $\begin{array}{l}\text { Red discs, male sterility long } \\
\text { cycle }\end{array}$ \\
\hline PAL & $\begin{array}{l}\text { Roadside and border } \\
\text { of a corn crop }\end{array}$ & $\begin{array}{l}\text { Less than } \\
50 \text { plants }\end{array}$ & $\begin{array}{l}\text { Wild and wild-crop } \\
\text { appearance }\end{array}$ \\
\hline GER & $\begin{array}{l}\text { Dirt road and inside } \\
\text { wheat crop }\end{array}$ & $\begin{array}{l}100-150 \text { plants } \\
\text { in } 1200 \mathrm{~m}^{2}\end{array}$ & $\begin{array}{l}\text { Seem volunteers with an- } \\
\text { thocyanin pigmentation }\end{array}$ \\
\hline
\end{tabular}

Taken as a group, the habitats of the wild sunflower populations in Argentina were different and allowed to explain the invasive process (Cantamutto et al., $2010 b)$. When compared to the Spanish populations, five of the agro-ecological variables differentiated the habitat from both countries by means of PCA (Figure 1). Among the Spanish populations, Gerona seems to have special features, different from those of Argentina and the remainder of the Spanish habitats. The most outstanding feature in populations from Andalusia was their presence within sunflower crops. 


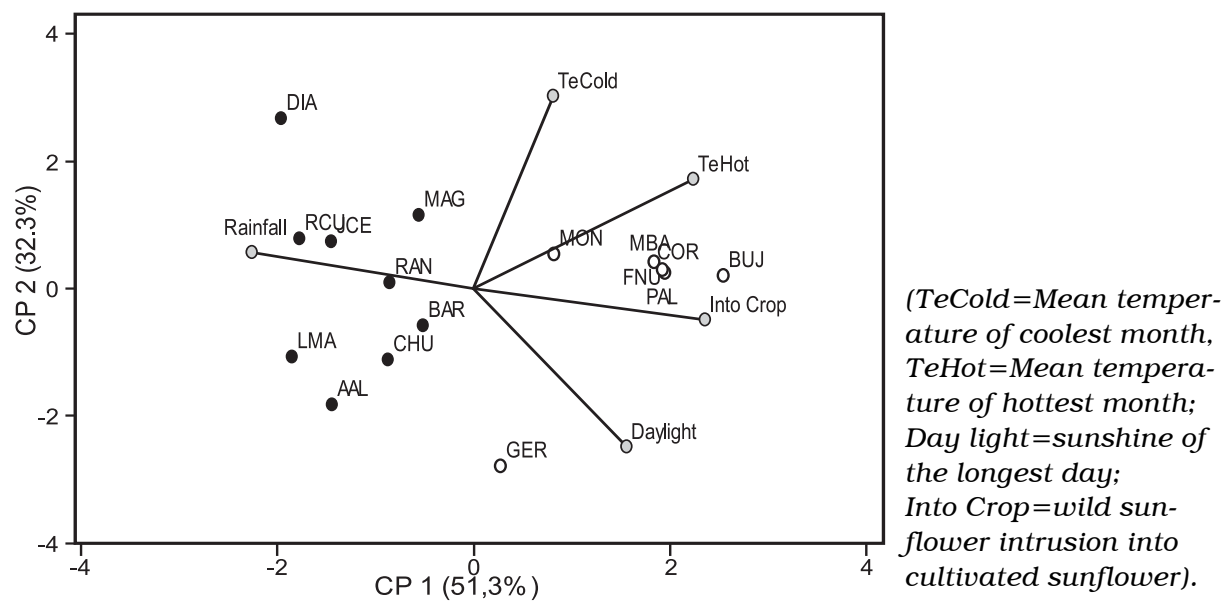

Figure 1: Ecological diversity of Argentinean and Spanish wild sunflowers habitats explained by a PCA biplot of the five most explicative variables. See population acronym in Tables 1 and 2.

\section{Plant morphology}

Plants were screened for 24 morphological traits, which allowed a fairly good classification of the 16 populations. Kruskal-Wallis nonparametric analyses showed that most metric traits were highly significantly different between the countries, whereas categorical traits did not differ to a comparable extent (Table 5). However, some of the latter showed significant differences in traits that are characteristic of wild or cultivated sunflower - anthocyanin presence and red disc flowers in the Argentinean populations, no branching and main head presence in the Spanish populations.

Table 5: Mean value (metric traits) and frequency (categorical traits) in Argentina and Spain and significance of differences by the Kruskal-Wallis non parametric test

\begin{tabular}{|c|c|c|c|}
\hline Metric traits & Arg. & Spain & Sign. \\
\hline Plant height $(\mathrm{cm})$ & 206 & 176 & * \\
\hline Stem diameter $(\mathrm{cm})$ & 1,8 & 1.8 & ns \\
\hline Head angle $\left({ }^{\circ}\right)$ & 76.8 & 86.5 & 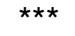 \\
\hline Leaf width $(\mathrm{cm})$ & 15.6 & 26.0 & $\star * *$ \\
\hline Leaf length $(\mathrm{cm})$ & 18.8 & 32.3 & $* * *$ \\
\hline Petiole length $(\mathrm{cm})$ & 12.4 & 19.9 & $\star \star *$ \\
\hline$N$ ligules $(n)$ & 25.6 & 34.3 & $\star \star \star *$ \\
\hline Ligule width $(\mathrm{cm})$ & 1.4 & 1.7 & $\star * \star$ \\
\hline Ligule length $(\mathrm{cm})$ & 4.0 & 5.8 & $* * *$ \\
\hline$N$ bracts $(n)$ & 36.9 & 39.7 & ** \\
\hline Bract width $(\mathrm{cm})$ & 1.2 & 1.7 & $\star \star \star$ \\
\hline Bract length $(\mathrm{cm})$ & 1.7 & 3.1 & $\star \star \star *$ \\
\hline Disc diameter $(\mathrm{cm})$ & 3.9 & 6.1 & $\star * \star$ \\
\hline
\end{tabular}

\begin{tabular}{lccc}
\hline Categorical traits & Arg. & Spain & Sign. \\
\hline Anthocyanin presence & 0.92 & 0.74 & $\star \star \star$ \\
No branching & 0.00 & 0.35 & $\star \star$ \\
Total branching & 0.11 & 0.14 & $\mathrm{~ns}$ \\
Main head presence & 0.00 & 0.28 & $\star \star$ \\
N heads $<10$ & 0.03 & 0.16 & $\mathrm{~ns}$ \\
(ranges) $11-25$ & 0.28 & 0.13 & $\mathrm{~ns}$ \\
$\mathrm{~N}$ heads $>25$ & 0.69 & 0.63 & $\mathrm{~ns}$ \\
Leaf base (cordate) & 0.68 & 0.93 & $*$ \\
Leaf shape (cordate) & 0.77 & 0.89 & $\mathrm{~ns}$ \\
Leaf surface & 0.10 & 0.29 & $*$ \\
Leaf margin & 0.33 & 0.12 & $\mathrm{~ns}$ \\
Dorsal leaflet & 0.54 & 0.35 & $\mathrm{~ns}$ \\
Dense bract pubescence & 0.00 & 0.25 & $*$ \\
Flower disc color (red) & 0.93 & 0.71 & * \\
\hline
\end{tabular}


On the whole, the Argentinean populations had taller plants with a higher number of heads of small size, while the Spanish ones were characterized by larger leaves and bigger heads with larger ligules and bracts. The plants were shorter and leaf size was larger in Gerona than in Andalusia.

Principal Component Analysis based on metric traits showed that the Argentinean and Andalusian populations spread along the first PC, the former showing a better clustering of individuals from each population. The population from Gerona was close to the Spanish group, but separated by the second PC. It also showed a loose clustering of individuals (Figure 2), indicating a high variability within this locality. However, these variables only explained $53 \%$ of the total variability.

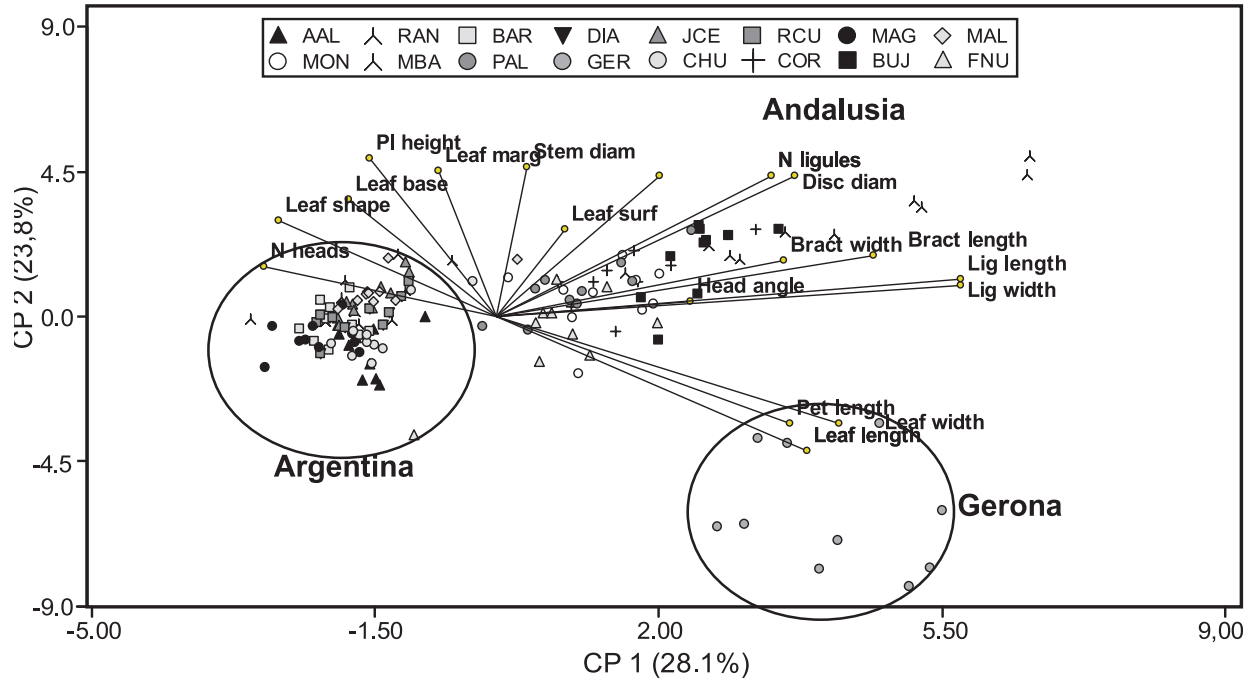

Figure 2: Morphological differentiation among wild sunflowers from Argentina and Spain in a PCA biplot based on standardized values for 17 traits. Plants are represented by points and traits by vectors from the origin. See Tables 1 and 2 for population acronyms and Table 5 for traits.

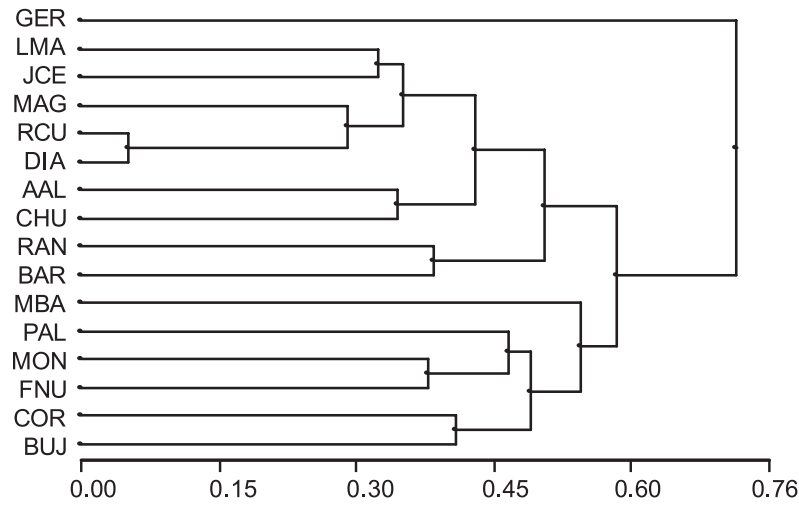

Figure 3: Overall similitude among 16 wild sunflower populations based on 24 morphological traits. UPGMA clustering was performed using Gower's distance matrix (Cophenetic correlation 0.95 ). See Tables 1 and 2 for population nomenclature.

Cluster analysis based on mean values of all the traits displayed two main clusters corresponding to both countries, while the Gerona population remained as a 
third group (Figure 3). Considering these three groups, discriminant analysis differentiated populations from Argentina and Spain mainly by leaf shape, branching, plant height, and head size and color. The Spanish populations clearly split in those from Andalusia and the one from Gerona. There was better differentiation among the Argentinean populations with a marked clumping of individuals, also showing a separation between Rancul (RAN) and Baron (BAR) and the remaining populations (Figure 4).

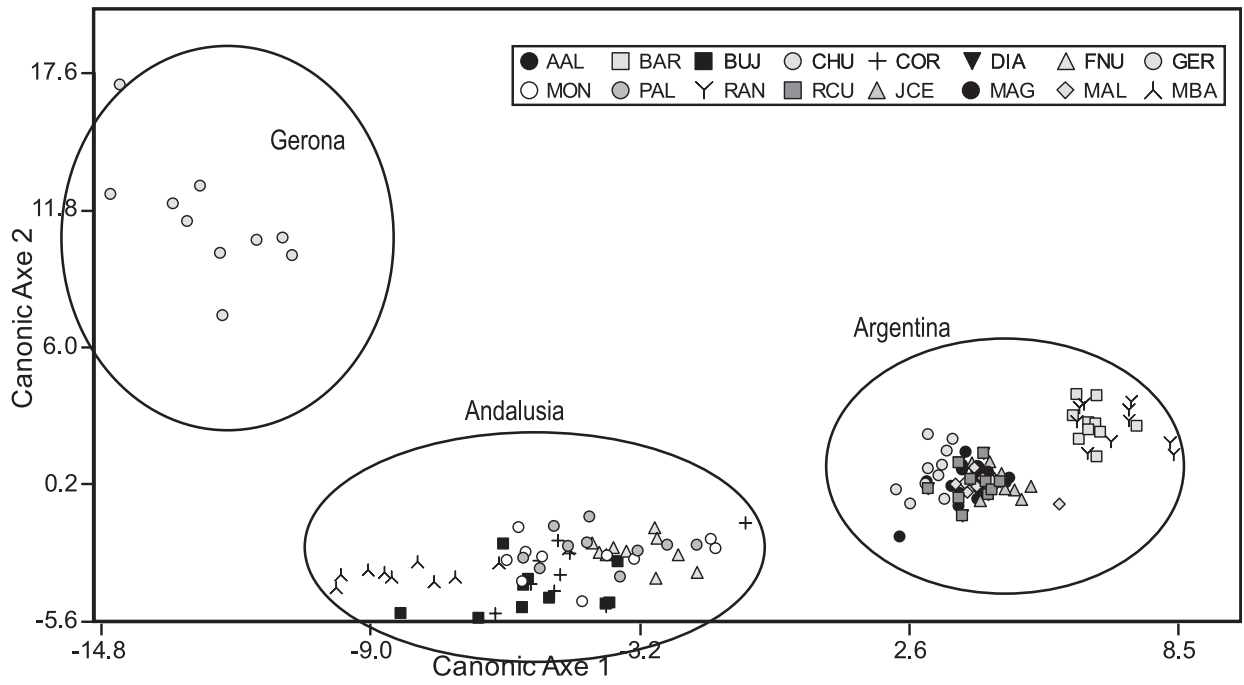

Figure 4: Discriminant analysis of 160 plants sampled in the field in Argentina and Spain based on 24 morphological traits. Each point represents the score for an individual. There is a noticeable grouping by populations.

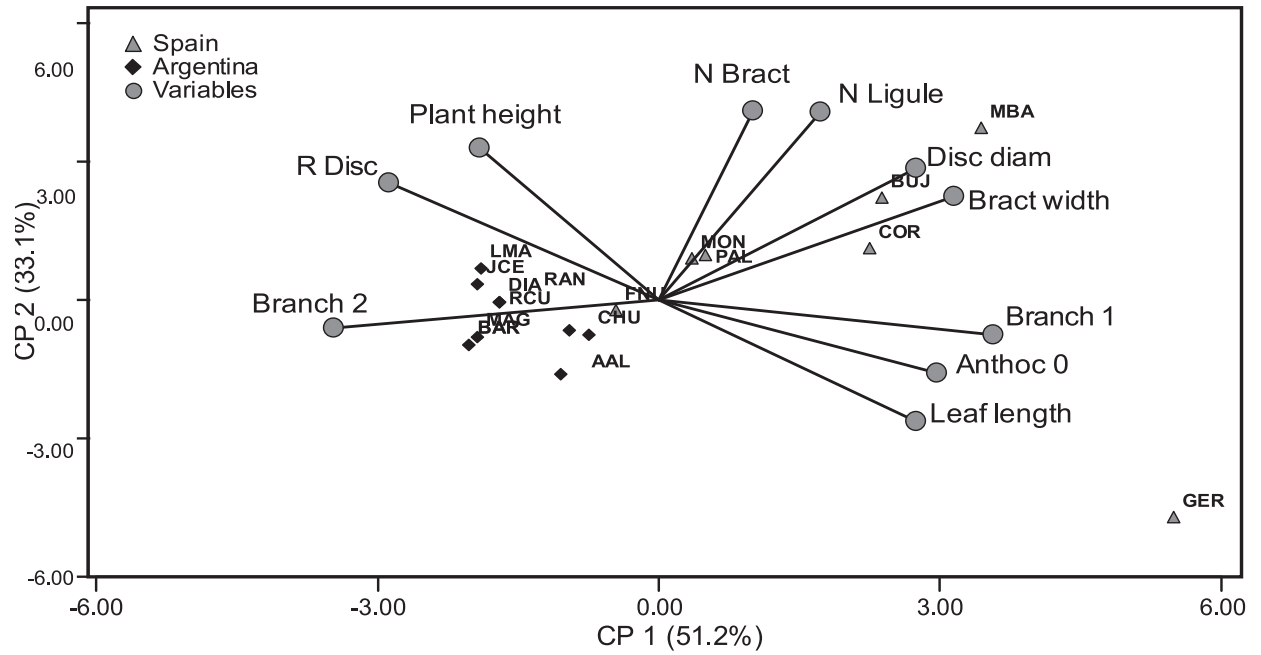

Figure 5: Biplot of the 10 variables that better explain the diversity among Argentinean and Spanish wild sunflower populations. See Tables 1 and 2 for population acronyms and Table 5 for traits. 
Taking into account categorical variables in PCA as well, there were 10 that retained more than $84 \%$ of the original information (Figure 5). Higher frequencies of no branching, absence of anthocyanin, large leaves, shorter plants and lower frequency of red discs were found in the Gerona population. On the other hand, profuse branching, tall plants and red disc flowers characterized the Argentinean populations, while the Andalusian ones had bigger heads with a higher number of ligules and bracts and wider bracts. Strong branching, reduced size of heads, and anthocyanin presence are typical wild traits (Burke et al., 2002). Muller et al. (2009) described some Andalusian populations as weedy plants growing between the rows of sunflower crop showing anthocyanin pigmentation, small discs, strong branching, and reduced apical dominance. Self incompatibility and seed dormancy were found among those plants. They also recorded similar plants outside sunflower fields and called them escaped weedy populations. Their finding of a combination of wild and domesticated traits was confirmed in this study.

Gene flow from wild and domestic sunflowers to weedy populations is likely the source of genetic variation among them. Hybridization among wild and cultivated $H$. annuus is fairly common under Argentinean conditions (Ureta et al., 2008a,b). Crop traits can be recognized in wild plants of some populations, for example AAL, MAG and LMA (Presotto et al., 2009). Another naturalized annual species in Argentina, $H$. petiolaris, can also hybridize with $H$. annuus and thus constitutes another source of variation (Gutierrez et al., 2009). However, morphological traits confirmed that naturalized Argentine populations correspond to the wild form of the species in comparison with North American populations (Cantamutto et al., 2010a).

\section{CONCLUSIONS}

Wild sunflower populations are established in non-tilled areas within the agricultural regions of central Argentina, between $32^{\circ}$ and $38^{\circ} \mathrm{S}$ latitude. In Spain, invasive sunflowers are found mainly in croplands between $36^{\circ}$ and $42^{\circ} \mathrm{N}$ latitude. In spite of the intensive gene flow between them and the cultivated sunflower, Argentinean populations seem to have retained a much wilder appearance than Spanish populations. Our morphological data seem to confirm the hypothesis on the origin of seed contamination with wild sunflower for Andalusian populations, while the population in Gerona was probably derived from volunteer plants.

\section{ACKNOWLEDGEMENTS}

We are grateful to Dr. Patricio García-Fayos from Centro de Investigaciones sobre Desertificación (CSIC-UVEG) of Valencia, Spain who kindly provided facilities for data analyses of Spanish materials. This research was supported by grants ANPCYT-PICT 2286 and UNS-PGI 24 A106. 


\section{REFERENCES}

Bauer, H.A., 1991. Cuarenta años en el mejoramiento del girasol (Helianthus annuus L.) en Argentina 1947-1987. Helia 14: 63-68.

Burke, J.M., Tang, S., Knapp, S.J., Rieseberg, L.H., 2002. Genetic analysis of sunflower domestication. Genetics 161: 1257-1267.

Cantamutto, M., Poverene, M., Peinemann, N., 2008. Multi-scale analysis of two annual Helianthus species naturalization in Argentina. Agriculture, Ecosystems and Environment 123: 69-74.

Cantamutto, M., Presotto, A., Fernandez Moroni, I., Alvarez, D., Poverene, M., Seiler, G., $2010 a$. High infraspecific diversity of wild sunflowers (Helianthus annuus L.) naturally developed in central Argentina. Flora 50351 (In press).

Cantamutto, M., Torres, L., Presotto, A., Gutierrez, A., Ureta, S., Poverene, M., 2010b. Migration pattern suggested by terrestrial proximity as possible origin of wild annual Helianthus populations in central Argentina. Biological Invasions (In press). DOI: 10.1007/s 10530009-9458-8.

Deines, S.R., Dille, J.A., Blinka, E.L., Regehr, D.L., Staggenborg, S.A., 2004. Common sunflower (Helianthus annuus) and shattercane (Sorghum bicolor) interference in corn. Weed Science 52: 976-983.

Dry, P.J. and Burdon, J.J., 1986. Genetic structure of natural populations of wild sunflowers (Helianthus annuus L.) in Australia. Australian J. Biological Science 39: 255-270.

Faure, N., Serieys, H., Berville, A., 2002. Potential gene flow from cultivated sunflower to volunteer, wild Helianthus species in Europe. Agriculture, Ecosystems and Environment 89: 183-190.

Geier, P.W., Maddux, L.D., Moshier, L.J., Stahlman, P.W., 1996. Common sunflower (Helianthus annuus) interference in soybean (Glycine max). Weed Technology 10: 317-321.

Gower, J.C., 1971. A general coefficient of similarity and some of its properties. Biometrics 27: 857-871.

Gutierrez, A., Carrera, A., Basualdo, J., Rodriguez, R., Cantamutto, M., Poverene, M., 2010. Gene flow between cultivated sunflower and Helianthus petiolaris (Asteraceae). Euphytica 172: 67-76. DOI 10.1007/s10681-009-0045-y (Online First).

Holec, J., Soukup, J., Cerovska, M., Novakova, K., 2005. Common sunflower (Helianthus annuus var. annuus) - potential threat to coexistence of sunflower crops in Central Europe. In: Proceedings $2^{\text {th }}$ Internal Conference on co-existence between GM and nonGM based agricultural supply chains, Montpellier, France, 14-15 Nov 2005, pp. 271-272.

Jan, C.C. and Seiler, G.J., 2007. Sunflower. In: Genetic Resources, Chromosome Engineering, and Crop Improvement. Volume 4: Oilseed Crops. Ram J. Singh (Ed.) CRC Press, Boca Raton, pp. 103-165.

Marshall, M., Al-Khatib, K., Loughin, T., 2001. Gene flow, growth, and competitiveness of imazethapyr-resistant common sunflower. Weed Science 49: 14-21.

Muller, M.H., Arlie, G., Bervillé, A., David, J., Delieux, F., Fernandez-Martinez, J.M., Jouffret, P., Lecomte, V., Reboud, X., Rousselle, Y., Serieys, H., Teissere, N., Tsitrone, A., 2006. Le compartiment spontané du tournesol en Europe: prospections et premičres caractérisations génétiques. Les Actes du BRG 6: 335-353.

Muller, M.E., Delieux, F., Fernandez Martinez, J.M., Garric, B., Lecomte, V., Anglade, G., Leflon, M., Motard, C., Segura, R., 2009. Occurrence, distribution and distinctive morphological traits of weedy Helianthus annuus L. populations in Spain and France. Genetic Resources and Crop Evolution 56: 869-877.

Poverene, M.M., Cantamutto, M.A., Carrera, A.D., Ureta, M.S., Salaberry, M.T., Echeverria, M.M., Rodriguez, R.H., 2002. El girasol silvestre (Helianthus spp.) en la Argentina: caracterización para la liberación de cultivares transgénicos. Revista de Investigaciones Agropecuarias 31: 97-116.

Poverene, M., Cantamutto, M., Seiler, G.J., 2008. Ecological characterization of wild Helianthus annuus and $H$. petiolaris germplasm in Argentina. Plant Genetic Resources. Characterization and Utilization (UK) 7: 42-49.

Presotto, A., Cantamutto, M., Poverene, M., Seiler, G., 2009. Phenotypic diversity in wild Helianthus annuus from Argentina. Helia 32: 37-49.

Reagon, M. and Snow, A.A., 2006. Cultivated Helianthus annuus (Asteraceae) volunteers as a genetic "bridge" to weedy sunflower populations in North America. American Journal of Botany 93: 127-133. 
Ribeiro, A., Bessa, A., Faria, T., 2005. Evaluation of wild Helianthus species in Mozambique. European Cooperative Research Network on Sunflower. FAO Working Group. Progress Report 2001-2004, pp. 46-48.

Seiler, G.J., Gulya, T.J., Kong, G., Thompson, S., Mitchell, J., 2008 Collection of wild naturalized sunflowers from the land down under. http://www.sunflowernsa.com/research/research-workshop/documents/ Seiler_etal_DownUnder_08.pdf

Ureta, S., Cantamutto, M., Carrera, A., Delucchi, $\bar{C}$., Poverene, M., 2008 a. Natural hybrids between cultivated and wild sunflowers in Argentina. Genetic Resources and Crop Evolution 55: 1267-1277.

Ureta, M.S., Carrera, A.D., Cantamutto, M.A., Poverene, M.M., 2008b. Gene flow among wild and cultivated sunflower, Helianthus annuus L. in Argentina. Agriculture, Ecosystems and Environment 123: 343-349.

Vischi, M., di Berardo, N., Scotti, I., della Casa, S., Seiler, G., Olivieri, A., 2004. Comparison of populations of Helianthus argophyllus and H. debilis subsp. cucumerifolius and their hybrids from the African Coast of the Indian Ocean and USA using molecular markers. Helia 27: 123-132.

Vischi, M., Cagiotti, M.E., Cenci, C.A., Seiler, G.J., Olivieri, A.M., 2006. Dispersal of wild sunflower by seed and persistent basal stalks in some areas of central Italy. Helia 45: 8994.

\title{
POBLACIONES INVASORAS DE Helianthus annuus EN ARGENTINA Y ESPAÑA
}

\author{
RESUMEN
}

Helianthus annuus silvestre es originario de América del Norte pero se encuentra también en otras partes del mundo. El origen de las poblaciones exóticas es incierto y probablemente han evolucionado muy diversamente en los distintos países. Para develar el origen de las poblaciones invasoras en Argentina y España, se colectaron datos morfológicos y agro-ecológicos de nueve poblaciones de la región central de Argentina, seis poblaciones de Andalucía y una de Girona, en su hábitat natural, durante tres viajes de exploración en 2007 y 2008. En Argentina, H. annuus silvestre fue hallado principalmente en áreas disturbadas entre caminos y alambradas. En unos pocos casos las poblaciones es encontraban localizadas en los márgenes de campos cultivados. Las poblaciones argentinas alcanzaron más de $50.000 \mathrm{~m}^{2}$ y una densidad de alrededor de 25 plantas $/ \mathrm{m}^{2}$. En España, las poblaciones se encontraron principalmente en tierras cultivadas. La de mayor tamaño cubría alrededor de $1500 \mathrm{~m}^{2}$ y contenía no más de 200 plantas. Las poblaciones argentinas mostraron plantas más altas con mayor número de capítulos de pequeño tamaño, mientras que las españolas se caracterizaron por tallos más robustos, capítulos más grandes con lígulas y filarias (brácteas) más anchas. Las plantas fueron más bajas y las hojas de mayor tamaño en Girona que en Andalucía. El análisis multivariado diferenció las poblaciones de Argentina y España por muchos rasgos. El flujo génico cultivo-silvestre es probablemente la fuente de variación genética entre ellas. En Argentina, las poblaciones mantienen el aspecto de las antiguas introducciones silvestres, mientras que las poblaciones españolas son más de tipo malezoide y probablemente se originaron en contaminación de semilla comercial por polen de plantas silvestres o híbridos cultivo-silvestre. 


\title{
POPULATIONS ENVAHISSEURS DE Helianthus annuus EN ARGENTINE ET EN ESPAGNE
}

\author{
RÉSUMÉ
}

Helianthus annuus sauvage il est originaire d'Amérique du Nord mais il se trouve aussi dans d'autres parties du monde. L'origine des populations exotiques est incertaine et probablement ont évolué très diversement dans les différents pays. Pour effiler l'origine des populations envahisseurs en Argentine et en Espagne, se on des données morphologiques et agro-écologiques de neuf populations de la région centrale de l'Argentine, six populations d'Andalousie et une de Girona, dans son habitat naturel, pendant trois voyages d'exploration en 2007 et 2008. En Argentine, H. annuus sauvage il a été trouvé principalement dans des secteurs perturbés entre des chemins et clôturés. Dans quelques cas les populations sont trouvaient localisées dans les marges de domaines cultivés. Les populations argentines ont atteint plus de $50.000 \mathrm{~m}^{2}$ et une densité d'autour de 25 plantes $/ \mathrm{m}^{2}$. En Espagne, les populations se sont trouvées principalement dans des terres cultivées. Celle de grande taille couvrait d'autour $1500 \mathrm{~m}^{2}$ et il contenait non plus de 200 plantes. Les populations argentines ont montré des plantes plus hautes avec un plus grand nombre de capitules de petite taille, tandis que les Espagnols se sont caractérisées par des tiges plus robustes, des capitules plus grands avec ligules et bractées plus larges. Les plantes ont été plus faibles et les feuilles de grande taille en Girona qui en Andalousie. L'analyse variable a différencié les populations l'Argentine et de l'Espagne par beaucoup de caractéristiques. Le flux des génes cultivé-sauvage est probablement la source de variation génétique entre elles. En Argentine, les populations maintiennent l'aspect des anciennes introductions sauvages, tandis que les populations espagnoles sont plus type mauvaise herbe et probablement en pollution de semence commerciale par pollen de plantes sauvages ou hybrides cultivé-sauvage. 